\title{
The inclusion of social data in integrated management of recreational activities: the example of crab gathering on Oléron Island (France)
}

\author{
G. Mossot \& V. Duvat \\ Department of Geography, UMR 6250, \\ La Rochelle University-CNRS, France \\ gabrielle.mossot@univ-lr.fr
}

\begin{abstract}
This article highlights the initial results of a trans-disciplinary and multi-partner research programme that provides solutions for the management of a recreational activity, crab gathering on rocky foreshores, to stakeholders in the territory of Oléron Island. A detailed analysis of the territory and of all the components of the "crab gathering system" enabled researchers to suggest appropriate responses to the territory's situation. We address the issues of how a combination of different disciplines with complementary methodologies can support territorial management; and how social science methodologies, and geography in particular, can contribute to the decision-making process.
\end{abstract}

Keywords: recreational crab gathering, multi-disciplinary, ICZM, Oléron Island, France

\section{Introduction}

Taking recreational activities into account for the purposes of territorial management and research is a recent approach that began in the 1990s. The goal of these initial studies was to quantify, in order to reduce, the impact of humans on a resource [1]. Later, researchers began to focus on particular environments, taking into consideration all of the characteristics of an area (environmental, social and economic). Such approaches also focused on the relationship between the practitioners of a recreational activity and the space in which they conduct these pursuits [2]. From the 2000s onwards, different fields of research began to be integrated with one another. Requirements started to change and scientific procedures began to focus more on the study of territories. Management policy issues have also changed gradually, shifting the emphasis to the analysis of entire territories, including environmental, social, political and economic factors and their interactions. Human frequentation studies were introduced, aiming to define the carrying capacities of environments [3,4] and territory observatories became a global tool for measuring changes in a given area [5]. Lastly, in the context of Integrated Coastal Zone Management, monitoring became an indispensable aspect, enabling managers to rethink their jurisdiction in an integrated and comprehensive way. Recreational activities, including recreational crab gathering, were progressively taken into account in territorial analyses. Social values, that are associated with activities and also territories, began to bring a qualitative dimension to the quantitative approaches developed thus far.

Oléron Island is the largest island on the French Atlantic coast $\left(175 \mathrm{~km}^{2}, 20,991\right.$ inhabitants in 2006). The tourism industry has boomed here since the 1960s when a bridge was built that linked the island to the mainland. Since then, tourism and recreational activities have played an important role in the island's economic life (the island's population doubles in summer). All population categories benefit from the increased accessibility of Oléron Island

This is an Open Access article distributed under the terms of the Creative Commons Attribution-Noncommercial License 3.0, which permits unrestricted use, distribution, and reproduction in any noncommercial medium, provided the original work is properly cited. 
and tourists day-trippers are now able to enjoy the island's qualities for periods as short as a single day. A wide range of the island's visitors partake in crab gathering, which is classified as a recreational activity. The Île d'Oléron Développement Durable et Environnement (Oléron Island Sustainable Development and Environment - IODDE) association $[6,7,8]$ estimated that 130,000 fishing trips were conducted between January and September 2007. The annual harvest is estimated at 330 tons for all species. Given these findings, in 2005 the Marennes Oléron District launched an Integrated Coastal Zone Management trial, which in 2007 produced the comprehensive management plan "Oléron Coastal Quality". This management plan focuses on the coastline and combines socio-economic objectives (improved user facilities, development of tourism activities, maintaining employment) with environmental objectives (in particular protection of the beaches, surrounding forests and tidal flats with high biodiversity). The main focus of the management plan is the organization and control of recreational and tourism activities, including crab gathering.

\section{The project and its main objectives}

\subsection{General overview of the GIPREOL programme}

The GIPREOL research programme (Integrated management of recreational practices on the foreshore: the example of crab gathering on Oléron Island, part of the ANR-Systerra programme) provides the territory's managers with an analysis of the area's resource usage system, through a combination of various disciplines (biology, geography and law). The objective is to contribute to the establishment of a plan for integrated and sustainable management of Oléron Island's coastal resources. The programme aims to characterize the multiple pressures generated by the practice of fishing on a target crab species, the velvet swimming crab (Necora puber), and also the disturbances to the ecosystem that this activity causes. The programme takes place over three years (2009 to 2011), each year representing one stage of the study. The first year involved an inventory, which focused on the resource, the practice, the management system and regulations. The second year, which is currently ongoing, is an in situ experimental phase. The aim is firstly to measure the response of the target species to different fishing pressures, and secondly to test the effectiveness of various awareness-raising methods. The final year of the programme will be dedicated to the evaluation of the results obtained. Have the actions implemented during year two had a beneficial effect on crab gathering practices?

Two pilot sites were chosen for the implementation of the programme. The first is located on the island's western coast (Saint-Denis d'Oléron) and the other on the eastern shore (Bréeles-Bains). Although these sites have different morphological and geographical characteristics, both are favourable for the development of the target species. An eroded limestone cliff that overlooks a pebble beach characterizes the site of Saint-Denis d'Oléron (Fig. 1), which is remote from villages and subject to heavy swells from the open sea. The site of Brée-les-Bains (Fig. 2) is located on the island's sheltered coast, next to the village of the same name. It has a sandy beach that continues for several meters towards the sea with alternating rocky outcrops and sandy deposits. The dissimilar characteristics of the two sites attract fishers with distinct profiles. 


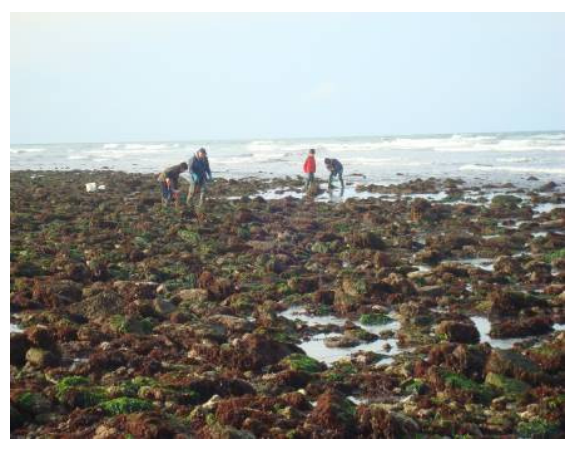

Figure 1: Boulder fields of the rocky foreshore of Saint-Denis d'Oléron

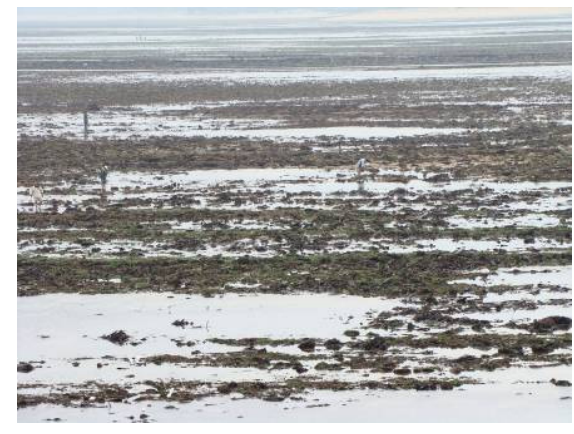

Figure 2: Rocky outcrops of the La Brée-les-Bains foreshore

\subsection{The contribution of geography in the GIPREOL programme}

The geography component of the GIPREOL programme aims to measure the potential of the territory's stakeholders to establish integrated management of recreational crab gathering. The programme comprises three stages, with each stage lasting one year.

The first year was dedicated to the analysis of the "stakeholder system", which includes "practitioners" and "authorities". The approach was designed to answer these questions: Who are the practitioners? Who are the stakeholders involved in the management of crab gathering and what are their roles and skills within the management system? What are the strengths and weaknesses of the territory for the implementation of integrated management of crab gathering? The second year will be an experimentation phase. By taking onboard the results of the previous stage, the aim will be to establish measures to strengthen and maintain the territory's potential for implementing integrated management of the activity. The final year will be a feedback phase with the objective of re-evaluating the territory's potential to see whether the actions carried out during year two have had beneficial effects on the management system.

\section{Methodology and scientific inquiry}

\subsection{Method and inquiry}

Two parallel methods have been developed to analyse the management system (Fig. 3).

The first approach focused on practitioners through the development of two lines of research: one aimed at the characterisation of the activity from qualitative (fisher status, motivation, yield, ancestral connection to the activity) and quantitative (estimated foreshore frequentation level) perspectives; the second line of research aimed at measuring the eco-citizenship potential of fishers and their propensity to participate in sustainable management policies for crab gathering. Eco-citizenship is defined here as the application of simple rules of environmental respect: the release of berried females, replacement of rocks that are moved while gathering, the release of undersized crabs, and a willingness to intervene with other practitioners who do not observe these rules of good practice. The objective of this first approach was to develop a first typology of practitioners taking into account the two lines of research, i.e. (1) fishing procedures and (2) fisher eco-citizenship potential. 
The second approach developed has focused on the stakeholders who manage the activity. The purpose was, firstly, to understand the organisation of the management system and, secondly, to measure its ability to establish an integrated management policy for the activity. To understand the management system, a "geographical" perspective was required to address several issues: What are the roles and skills of the stakeholders? What interactions exist between the different structures represented by the stakeholders? In the same way, other questions were raised to assess the potential for integrated management: What actions have stakeholders implemented to improve the management of the activity? Are actions between different structures coordinated? What are the future wishes of stakeholders for crab gathering management? The objective of this second approach is to highlight the strengths and weaknesses of the management system for implementing integrated management of foreshore species gathering.

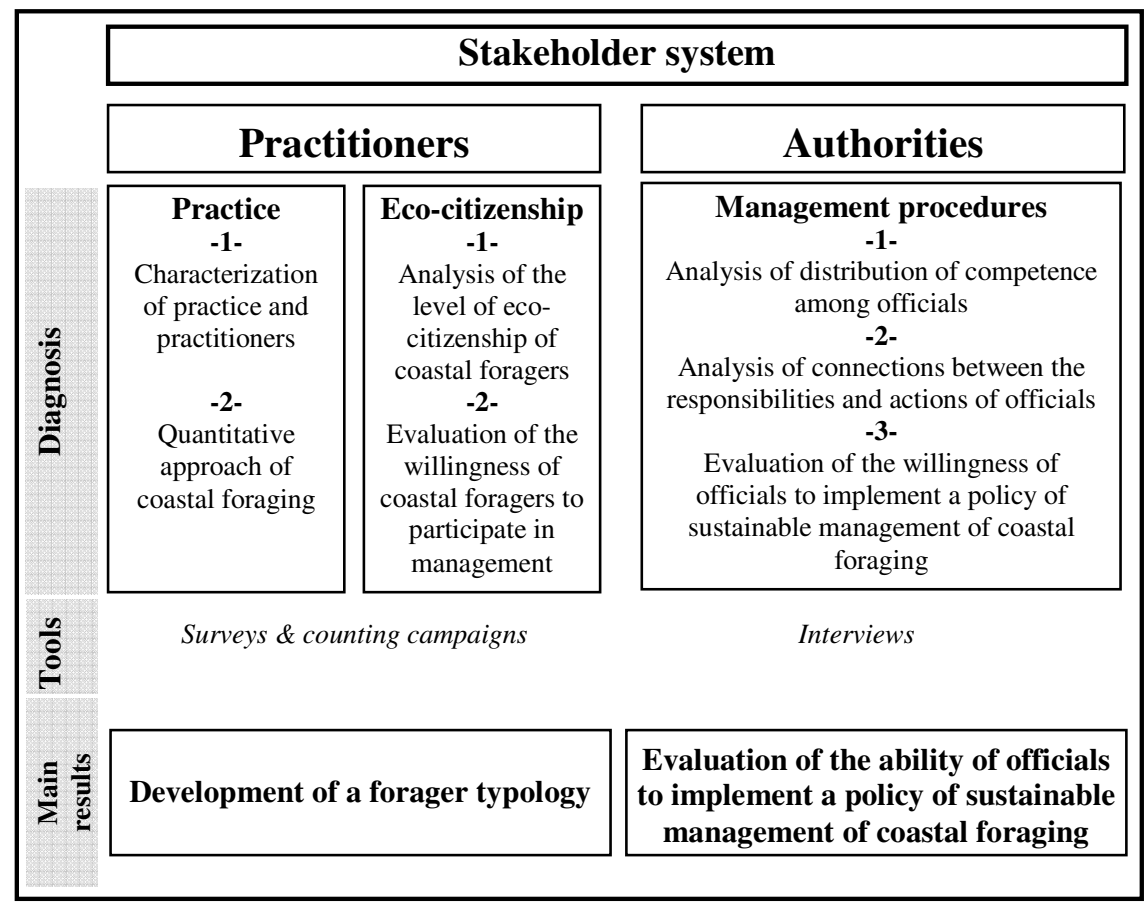

Figure 3: Presentation of the scientific procedure followed to analyze the stakeholder system (GIPREOL research programme)

\subsection{Tools developed for the process}

Various tools have been utilised to answer these questions. The study of the "practitioners" component was conducted using tools such as surveys, field observations and regular counting campaigns, while interviews were conducted to address the "authorities" component.

The practitioner survey was organised around these major themes:

- Information about the interviewee (sex, age, category, practitioner's companions, place of origin, motivation, experience in the activity)

- The practice of gathering (preparation for fishing trip, frequency, instruction in the practice, observation of simple gestures of good practice)

- A practitioner's knowledge of the species sought, the environment and of the authorities 
responsible for this activity.

- The importance of the activity for the practitioner and their perception of the richness of the foreshore.

- Fisher desire to become involved (willingness to share experiences and to participate in the management of the practice).

- Interactions and conflicts (frequency and nature of conflicts on the foreshore)

This survey applied a qualitative approach that involved posing a significant number of questions (132) to a small number of practitioners (about 50). In view of the observed average foreshore frequentation (a maximum of a few dozen fishers outside the tourist season), and of the high loyalty of practitioners to their fishing spot (high return rate), the results produced are representative. 32 practitioners were interviewed on the site of SaintDenis d'Oléron between March and May 2009 (outside the summer season), and 21 were surveyed in Brée-les-Bains in summer, during the spring tides of July 2009. In total, 53 questionnaires were completed. The chosen investigation periods enabled the sampling of a representative population, including permanent residents and others.

The methodology developed for the authority component was based on a stakeholder interview that focused on these major themes:

- Roles and skills within the foreshore fishing management system

- Vision and knowledge of the activity

- How the institutions represented by stakeholders take the activity into account

- Connection between the various projects in place on the territory

- Consultation and collaboration between institutions

- The decision-making process and the bottom-up management capacity

- Future outlook and intentions regarding foreshore species gathering

The interviews consisted of a general section that was received by all stakeholders, with additional specific questions according to the particular scope of each authority. A total of twelve stakeholders involved in the management of the activity, from the local to the national scale, were interviewed.

\section{Results}

The applied methodology enabled the initial questions to be answered. The results are presented according to each of the components of the system, and then compared and contrasted to highlight areas of progress and the territorial assets that would be of value for the successful implementation of integrated management of foreshore gathering.

The methodology developed for the "practitioners" component has enabled the accomplishment of: an inventory of the activity, the definition of a traditional practitioner's typical profile, and finally, an initial practitioner typology.

The practice of crab gathering is ancestral. Originally it was a subsistence activity, whereas today practitioners regard it as a hobby for relaxation, which is conducted in the liberating environment of the foreshore. The practice is now valuable in terms of cultural heritage and merits conservation. The traditional practitioner is a mature male, originally from a coastal region, who typically carries out this activity alone and has done so for at least 25 years. His expertise is inherited from his ancestors who also practiced crab gathering. Such a practitioner has a good understanding of the foreshore, its size, morphology and the species 
found here. He is very attached to his gathering area, the location of which he guards jealously.

Not all practitioners belong to this category. The results have identified five groups ranging from the local practitioner, who is an experienced eco-citizen (falling into the traditional practitioner category) to the amateur practitioner who is often a tourist and only fishes on holiday. The practitioner profiles have been defined on the basis of four criteria groups:

- Education (practitioner category, level of experience, how gathering techniques were learnt, yield).

- Methods employed and associated values (equipment used, motivation, gathering frequency, prior preparations made).

- Sense of custodianship of the foreshore (selection of a preferential fishing zone, how a fishing spot is chosen).

- Practitioner eco-citizenship (estimation of intertidal biodiversity, respectful gathering practices, willingness to change practices, co-management potential).

Five profiles have been identified based on these criteria, they are represented schematically in figure 4.

\begin{tabular}{|c|c|c|c|c|}
\hline $\begin{array}{l}\text { Group 5 } \\
\text { Amateur } \\
\text { practitioners }\end{array}$ & $\begin{array}{c}\text { Group 4 } \\
\text { Opportunistic } \\
\text { practitioners }\end{array}$ & $\begin{array}{l}\text { Group 3 } \\
\text { Ill-informed } \\
\text { frequent } \\
\text { practitioners }\end{array}$ & $\begin{array}{c}\text { Group 2 } \\
\text { Responsible } \\
\text { frequent } \\
\text { bractitioners }\end{array}$ & $\begin{array}{c}\text { Group 1 } \\
\text { Local, experienced } \\
\text { and eco-citizen } \\
\text { practitioners }\end{array}$ \\
\hline \multicolumn{2}{|l|}{ Bad practice } & & \multicolumn{2}{|r|}{ Good practice } \\
\hline \multicolumn{3}{|c|}{$\begin{array}{l}\text { Poor knowledge } \\
\text { Low sense of custodianship } \\
\text { Low eco-citizenship }\end{array}$} & \multicolumn{2}{|c|}{$\begin{array}{l}\text { Good knowledge } \\
\text { Strong sense of custodianship } \\
\text { Strong eco-citizenship }\end{array}$} \\
\hline
\end{tabular}

Fig. 4: Initial typology of practitioners

These types of qualitative criteria enable the real distinctions between the identified practitioner groups to be highlighted. Although practitioners mostly originate from coastal regions they do not all fall into the same category, as local residents and tourists alike come to fish on the foreshore. Depending on their region of origin and their background, the practitioners do not give equal importance to the foreshore. To the resident, the foreshore represents a familiar and well-defined area; this open space forms part of the practitioner's daily life. He knows the species that are present on a specific foreshore and the periods during which such species are abundant. This fisher has acquired a real knowledge of the foreshore and of species cycles. For the tourist, the foreshore is a place of discovery, which he only benefits from during holiday time. For this practitioner the foreshore occupies a space outside of everyday life that he is not familiar with and does not understand. Such variation in practitioner knowledge (in terms of biodiversity, species, foreshore delimitation) leads to divergent practices and levels of expertise. Therefore, practitioners exhibit a wide range of behaviours and practices that differ in their environmental impact.

The methodology applied to both the management system and the stakeholders has enabled the identification of three main outcomes: the understanding of the management system in 
place and the links between the role and actions of each stakeholder; the stakeholder vision of the activity and their wishes regarding the future of the activity; and the highlighting of the strengths of the management system and the areas where improvements can be made for the establishment of integrated management of recreational activities.

Many stakeholders are involved directly or indirectly in the government of foreshore species gathering. They all have different roles, skills and areas of intervention. It can be said that there are two main intervention scales - the local and the national scale. The national scale is represented by state institutions that work at the departmental level. These organisations have decision-making powers and can apply and modify laws. However, given the scale of the territory over which they have responsibility, recreational practices are not a priority. State institutions suffer from a lack of financial and human resources to control commercial and recreational fishing, from collection to consumption. As for the local stakeholders, recreational practices that take place in the Maritime Public Domain do not fall directly under their jurisdiction. Nevertheless the management of recreational activities is a major issue for an island. The analysis of the management system has highlighted the dualism that exists between state institutions that have decision-making powers but lack the means to act, and dynamic local stakeholders who carry out projects but are only able to act by conducting analyses and awareness-raising actions. The motivation for action and the initiatives to take originate at the local level and are submitted at the national level (bottom-up). Conversely, decisions are taken at the national level and applied at the local scale (top-down). This situation is poorly compensated by collaboration between the different structures.

Despite this management system, which is largely due to the French administrative organisation, the stakeholders have a coherent view of the activity. They are aware of the importance of the practice in terms of the attractiveness of Oléron Island, and see it as a leisure pursuit with significant heritage value. However they also noted the way the activity has evolved and that its practitioners have multiplied and diversified. For this reason, stakeholders today seek to find a balance between maintaining the practice and the preservation of biodiversity. They aim to identify means of action that are tailored to the local situation and would involve, among other aspects, the popularization of regulations and good foreshore gathering practices. This shared vision of stakeholders and their agreement on key issues are critical elements in the establishment of a territorial project. The integration of recreational activities into the Oléron Coastal Quality project, which is an operational framework, highlights the dynamism of the territory.

\section{Conclusion and discussion}

The results of the analysis of the " stakeholder system" firstly provide answers for the other disciplines involved in this research programme and secondly, assist those responsible for the management of the activity, according to their remit, regarding which measures should be considered for implementation.

Through a comparison of the results from the three disciplines involved, the typology of practitioners will enable measures to be suggested to managers that are adapted to the local environment (species, activity, practitioner types, remit of the relevant authorities). Initially, the combination of the quantitative results of biologists on the target species, and the qualitative data obtained, will help to quantify practitioner impact on the resource. Depending on the characteristics of their methods (gathering frequency, species collected, months during which species are collected, quantities taken), practitioners have different impacts. Biologists will thus be able to quantify practitioner impacts based on the description of their 
methods. Practitioners identified as having the biggest impact or who have no knowledge of the species or the environment can be educated. The survey provides additional results regarding the type of awareness-raising initiatives that can be successfully implemented.

The use of these data along with the study of legal aspects will help to obtain legal solutions that are adapted to the local situation. Through benefiting from the analysis of the situation and the observations made regarding the "practitioners" and "management system" components, legislators will be more able to propose appropriate measures. Such measures would represent soft laws that aimed firstly at the empowerment of practitioners through awareness raising, which is specific to each practitioner category, and secondly to strengthen species regeneration by introducing restricted zones on a rotational basis. By combining the results of all the disciplines involved, this programme shows that qualitative and social data are complementary to quantitative data for the characterization of an activity. Furthermore, the study of a particular territory shows how research can be of assistance to management by identifying measures adapted to the local situation.

The inclusion of recreational activities and, more particularly, of foreshore fishing in management measures is an emerging issue. At the local level, networks are under construction. Oléron Island is currently establishing a Permanent Centre for Environmental Initiatives, the role of this NGO is one of territorial support and environmental education, it will enable the harmonization and maintenance of the awareness-raising measures engaged. At the national level, the issue is also emerging and networks are being built in a similar way. In March 2010, the second national recreational fishing day took place and one of the meeting's conclusions was the need to maintain the sharing of questions, methodologies and results obtained. These exchanges showed that the problem is novel and that it still raises many issues that must be addressed by management measures.

\section{References}

[1] Kingsford, M.J. \& Underwood, A.J. \& Kennelly, S.J., Humans as predators on rocky reefs in New South Wales, Australia. Marine Ecology Progress Series, 72, pp. 1-14, 1991.

[2] Papinot, C., Requalifications du littoral et conflits d'usage: l'estran-environnement et l'estran-territoire. Sociétés Contemporaines, 52, pp. 105-121, 2003.

[3] VivArmor Nature, Projet de Contrat Nature Gestion durable de l'activité récréative de pêche à pied et préservation de la biodiversité littorale, 11 pages, 2007.

[4] Delisle F., 2004, Gestion de la fréquentation pour la conservation des habitats et des espèces sur l'îlot du Verdelet: site Natura 2000 de la baie de Saint-Brieuc, DESS "Activités et aménagements littoraux et maritimes", Université de Montpellier, 102 pages.

[5] Le Berre, S., Les observatoires de la fréquentation, outils d'aide à la décision des îles et des littoraux. Thèse de doctorat de géographie. Université de Bretagne Occidentale, 816 pages, 2008.

[6] Île d'Oléron Développement Durable (IODDE), La pêche à pied récréative sur Oléron, programme REVE 2006 - 2009, rapport intermédiaire de diagnostic, 80 pages, 2006. 
[7] Île d'Oléron Développement Durable (IODDE), La pêche à pied récréative sur Oléron, programme REVE 2006 - 2009, second rapport intermédiaire de diagnostic, 118 pages, 2007.

[8] Île d'Oléron Développement Durable (IODDE), La pêche à pied récréative sur Oléron, programme REVE 2006 - 2009, rapport de diagnostic, 65 pages, 2008. 